\title{
Quality of forage stockpiled in Wisconsin
}

\author{
JANET L. HEDTCKE, DANIEL J. UNDERSANDER, MICHAEL D. CASLER, AND DAVID K. COMBS
}

Authors are Research Specialist, Agronomy Dept., University of Wisconsin, Madison, Wisc. 53706 (jlrieste@facstaff.wisc.edu)., Professors, Agronomy Dept., University of Wisconsin, Madison, Wis. 53706, and Associate Professor, Dairy Science Dept., University of Wisconsin, Madison, Wisc. 53706. At the time of research, senior author was Research Assistant, Agronomy Dept., University of Wisconsin, Madison, Wisc. 53706.

\begin{abstract}
Stockpiling forage is a commonly used method to extend the grazing season in the southern U.S.A. However, there is little data on stockpiled forage in the upper Midwest. This study was conducted to determine the quality changes of 7 stockpiled coolseason grasses [early and late maturing orchardgrass, Dactylis glomerata L., quackgrass, Elytrigia repens (L.) Desv. Ex. Nevski, reed canarygrass, Phalaris arundinacea $\mathrm{L}$., smooth bromegrass, Bromus inermis Leyss., tall fescue, Festuca arundinacea Schreb., and timothy Phleum pratense $\mathrm{L}$.$] , with and without \mathrm{N}$ fertilizer, in Wisconsin. Forage was sampled at 3 offseason dates at 3 sites. To determine if $\mathbf{N}$ improved forage quality, $4 \mathrm{~N}$-fertilizer treatments were imposed: 0 or $67 \mathrm{~kg} \mathrm{~N} \mathrm{ha}^{-1}$ applied at start of stockpiling and 2 treatments totaling $168 \mathrm{~kg} \mathrm{~N} \mathrm{ha}^{-1}$ applied in the fall and spring. Over winter, crude protein (CP) decreased from 116 to $107 \mathrm{~g} \mathrm{~kg}^{-1}$, neutral detergent fiber (NDF) increased from 594 to $667 \mathrm{~g} \mathrm{~kg}^{-1}$, acid detergent fiber (ADF) increased from 367 to 435 $\mathrm{g} \mathrm{kg}^{-1}$, and in vitro organic matter digestibility (IVOMD) fell from 734 to $655 \mathrm{~g} \mathrm{~kg}^{-1}$. Nitrogen fertilizer improved CP in most environments but generally did not affect IVOMD, NDF, or ADF. Smooth bromegrass and quackgrass ranked highest in CP concentration and tall fescue ranked lowest. Timothy and latematuring orchardgrass ranked highest in IVOMD while quackgrass and reed canarygrass consistently ranked lowest. Quality of all stockpiled forage studied can maintain livestock such as beef cattle or dry dairy cows over winter if the forage is accessible and adequate animal stocking density is maintained.
\end{abstract}

Key Words: Stockpiling, forage quality, winter grazing, cool-season grasses

Rotational grazing is an increasingly common and effective method used to reduce the amount of forage that must be mechanically harvested and stored. In a typical upperMidwestern grazing system, pasture is generally available to the grazing animal from late April to late October. Beyond these months, grazing animals must be fed with stored forage. Combining stockpiling with rotational grazing may help producers manage pastures throughout the year and reduce winter feed costs, while efficiently utilizing pasture forage. Labor can be reduced to $25 \%$ of that for conventional wintering of beef cows (Van Keuren 1970).

By stockpiling pasture, feed can be provided to grazing animals well into December and possibly longer if ice and snow do not prevent grazing. Cattle and sheep can graze through as much as $0.5 \mathrm{~m}$ of fresh snow as long as there is a good supply of ungrazed forage below (Decker 1988). However, as winter progresses,

\footnotetext{
Manuscript accepted 24 Mar. 01.
}

\section{Resumen}

El almacenamiento de forraje en pie es un método comúnmente utilizado para extender la estación de apacentamiento en el sur de Estados Unidos. Sin embargo, en la parte superior del Medio Oeste de Estados Unidos hay poca información sobre este método. Este estudio se condujo en Wisconsin para determinar los cambios en la calidad del forraje almacenado en pie de 7 especies de zacates de estación fría ["Orchardgrass", Dactylis glomerata L.(maduración temprana y tardía), "Quackgrass", Elytrigia repens (L.) Desv. Ex. Nevski, "Reed canarygrass", Phalaris arundinacea L., "Smooth bromegrass", Bromus inermis Leyss., "Tall fescue", Festuca arundinacea Schreb. y "Timothy" Phleum pratense $\mathrm{L}$.] cultivados con y sin fertilización nitrogenada. El forraje se muestreo en 3 fechas fuera de la estación de crecimiento en 3 sitos de Wisconsin. Para determinar si el $\mathbf{N}$ mejoró la calidad del forraje se aplicaron 4 tratamientos de N: 0 or $67 \mathrm{~kg} \mathrm{~N}$ ha-1 aplicados al inicio de la etapa de almacenamiento del forraje y 2 tratamientos totalizando $168 \mathrm{~kg} \mathrm{~N}$ ha-1 aplicados en otoño y primavera. En el invierno la proteína cruda (PC) disminuyó de 116 a $107 \mathrm{~g} \mathrm{~kg}^{-1}$, la fibra neuto detergente (FND)aumentó de 594 to $667 \mathrm{~g} \mathrm{~kg}^{-1}$, la fibra ácido detergente (FAD) aumentó de 367 to $435 \mathrm{~g} \mathrm{~kg}^{-1}$ y la digestibilidad in vitro de la materia orgánica (DIVMO) diminuyó de 734 to $655 \mathrm{~g} \mathrm{~kg}^{-1}$. La fertilización nitrogenada mejoró el contenido de protína cruda en la mayoría de los ambientes, pero generalmente no afecto la DIVMO, FND, o la FAD. EI "Smooth bromegrass" y "Quakgrass" presentaron los mayores contenidos de PC y el "Tall fescue" el menor. El "Timothy" y el "Orchardgrass" de maduración tardía se mostraron los más altos porcentajes de DIVMO mientras que el "Quackgrass"y "Reed canarygrass" presentaron en forma consistente los mas bajos porcentajes. La calidad del forraje almacenado en pie que se estudio puede mantener durante el invierno al ganado, tal como los bovinos para carne o vacas lecheras secas, si el forraje es accesible y se utiliza y mantiene una densidad de carga animal adecuada.

grasses tend to lay down under the weight of the snow, ice, and wind, increasing leaf rot and decay and thus decreasing palatability and nutritional value.

Yield and intake of stockpiled forage was reported by Riesterer et al. (2000b). In contrast, quality of forage stockpiled in the upper Midwest has not been reported. The objectives of this study were to compare over-winter quality changes of several stockpiled cool-season grasses common to upper Midwest pastures, with and without $\mathrm{N}$ fertilization. This data will permit us to estimate the ability of different stockpiled forages to meet the nutritional needs for different animal classes out-wintered on pasture and will allow us to more accurately calculate the appropriate animal stocking density 


\section{Materials and Methods}

Field research was carried out at the University of Wisconsin Agricultural Experiment Stations near Arlington $\left(43^{\circ}\right.$ $\left.18^{\prime} \mathrm{N}, 89^{\circ} 21^{\prime} \mathrm{W}\right)$, Lancaster $\left(42^{\circ} 50^{\prime} \mathrm{N}\right.$, $\left.90^{\circ} 47^{\prime} \mathrm{W}\right)$, and Marshfield, Wisc. ( $44^{\circ} 39^{\prime}$ $\mathrm{N}, 90^{\circ} 8^{\prime} \mathrm{W}$ ), during 1995 to 1998 . The soil types were Plano silt loam (fine-silty, mixed, mesic, Typic Argiudoll) at Arlington, Rozetta silt loam (fine-silty, mixed, mesic, Typic Hapludalf) at Lancaster, and Withee silt loam (fineloamy, mixed, frigid, Aeric Glossaqualf) at Marshfield.

Soil samples were taken once each spring to a $15-\mathrm{cm}$ depth at each site. Soil samples were analyzed for $\mathrm{pH}$, organic matter, available $\mathrm{P}$, and extractable $\mathrm{K}$ by the University of Wisconsin Soil and Plant Analysis Laboratory using the procedures of Schulte et al. (1987). Soil tests at the Arlington site indicated a soil $\mathrm{pH}$ near 6.5, organic matter content of $3.9 \%$, P levels at $49 \mathrm{mg} \mathrm{kg}^{-1}$, and $\mathrm{K}$ levels at $155 \mathrm{mg} \mathrm{kg}^{-1}$. Lancaster soil tests revealed a slightly higher $\mathrm{pH}$ of 6.8 , organic matter content of $3.2 \%$, P levels at $28 \mathrm{mg} \mathrm{kg}^{-1}$, and $\mathrm{K}$ levels at $105 \mathrm{mg} \mathrm{kg}^{-1}$. Soils at Marshfield had a $\mathrm{pH}$ of 7.0 , organic matter content of $3.5 \%$, $\mathrm{P}$ levels at $32 \mathrm{mg} \mathrm{kg}^{-1}$, and $\mathrm{K}$ levels at 125 $\mathrm{mg} \mathrm{kg}^{-1}$.

Seven cool-season grasses, 'AC Nordic' (late maturity) and 'Benchmark' (early maturity) orchardgrass [Dactylis glomerata L.], 'Roseau' quackgrass [Elytrigia repens (L.) Desv. Ex. Nevski], 'Palaton' reed canarygrass [Phalaris arundinacea L.], 'Alpha' smooth bromegrass [Bromus inermis Leyss], 'Barcel' tall fescue [Festuca arundinacea Schreb], and 'Colt' timothy [Phleum pratense L.] were established at these 3 sites in the spring of 1995. Land was prepared with a soil digger followed by a culti-packer. Grass seed was drilled in seven, $15-\mathrm{cm}$ rows within the plot at the Lancaster and Arlington sites, and in five, $15-\mathrm{cm}$ rows at the Marshfield site (using a Tool Carrier 2700 Wintersteiger drill ${ }^{1}$, Salt Lake City, Ut.). Plot size was $1.2 \times 3.7 \mathrm{~m}$ at Arlington and Lancaster and $0.9 \times 6.1 \mathrm{~m}$ at Marshfield. A border of 'Martin' tall fescue was planted around each plot of quackgrass to reduce the potential of interplot contamination by rhizome spreading (Casler and Goodwin 1998). At planting and again on 1 August, plots received $67 \mathrm{~kg} \mathrm{~N} \mathrm{ha}^{-1}$ from $\mathrm{NH}_{4} \mathrm{NO}_{3}$ applied with a drop spreader. All stands

\footnotetext{
'Trade names mentioned for the reader's convenience, and do not imply endorsement by the Univ. of Wisc.
}

Table 1. Rates and schedules of 4 -fertilization treatments.

\begin{tabular}{|c|c|c|c|}
\hline $\begin{array}{l}\mathrm{N} \text {-fertilization } \\
\text { treatment }^{1}\end{array}$ & Late summer ${ }^{2}$ & Early spring $^{3}$ & Late spring ${ }^{4}$ \\
\hline & \multicolumn{3}{|c|}{$\ldots \ldots \ldots \ldots\left(\mathrm{kg} \mathrm{ha}^{-1}\right) \ldots \ldots \ldots \ldots \ldots \ldots$} \\
\hline F0 & 0 & 0 & 0 \\
\hline F67(1) & 67 & 0 & 0 \\
\hline F168(2) & 67 & 0 & 101 \\
\hline F168(3) & 67 & 45 & 56 \\
\hline
\end{tabular}

Each $\mathrm{N}$ treatment shows the total $\mathrm{kg} \mathrm{N}$ ha- 1 and the number of applications in parenthesis

2 Aug. 1996 and 1997.

${ }^{3} 15$ Apr. 1997 and 8 Apr. 1998.

${ }^{4} 1$ Jun. 1997 and 20 May 1998.

had nearly $100 \%$ ground cover at the beginning of the study.

Four $\mathrm{N}$ treatments were imposed (Table 1). Plots received 1 of 2 fertility treatments in late summer, either a control, 0 (F0), or $67[\mathrm{~F} 67(1)] \mathrm{kg} \mathrm{N}^{-1}$ on 1 August, which coincided with the start of stockpiling. Two other fertility treatments were applied in the spring and at the start of stockpiling in late summer. The F168(2) treatment was an application of $101 \mathrm{~kg} \mathrm{~N} \mathrm{ha}^{-1}$ after the first spring cut (late May) and $67 \mathrm{~kg} \mathrm{~N} \mathrm{ha}^{-1}$ on 1 August. The F168(3) treatment was a split application of $45 \mathrm{~kg} \mathrm{~N}$ ha-1 applied before the first spring cut (early April) and $56 \mathrm{~kg} \mathrm{~N} \mathrm{ha}{ }^{-1}$ applied after the first spring cut, as well as $67 \mathrm{~kg} \mathrm{~N} \mathrm{ha}^{-1}$ on 1 August. The effect of the spring $\mathrm{N}$ treatments on seasonal yield distribution and carry over to fall stockpiling is reported in Riesterer et al. (2000a,2000b).

During the 1996 and 1997 growing seasons, all plots were mechanically harvested to an 8-cm stubble with a flail chopper when the tallest plots reached a $30-\mathrm{cm}$ height, ending on 1 August. Forage accumulated after 1 August was primarily leafy, vegetative material that was harvested as three stockpiling treatments during the off-season: 1) near the first killing frost, 2) mid-December, and 3) late March or early April (Table 2), these treatments are hereafter referred to as the October, December, and March harvest dates, respectively.

Table 2. Dates of first killing frost and harvest schedule at Arlington, Marshfield, and Lancaster, Wisc. in 1996 and 1997.

\begin{tabular}{|c|c|c|c|c|c|}
\hline \multirow[b]{2}{*}{ Year } & \multirow[b]{2}{*}{ Site } & \multirow[b]{2}{*}{ Kiling frost } & \multicolumn{3}{|c|}{ Harvest date } \\
\hline & & & $1 \mathrm{st}$ & 2nd & 3 rd \\
\hline \multicolumn{6}{|l|}{$\overline{1996}$} \\
\hline & Arlington & 3 Oct. & 8 Oct. & 13 Dec. & 31 Mar. \\
\hline & Marshfield & 3 Oct. & 1 Oct. & 1 Dec. & 10 Apr. \\
\hline & Lancaster & 3 Oct. & 9 Oct. & 17 Dec. & 24 Mar. \\
\hline \multicolumn{6}{|l|}{1997} \\
\hline & Arlington & 15 Oct. & 20 Oct. & 3 Dec. & 30 Mar. \\
\hline & Marshfield & 25 Oct. & 9 Oct. & $1 \mathrm{Dec}$. & 3 Apr. \\
\hline & Lancaster & 26 Oct. & 3 Nov. & 28 Dec. & 30 Mar. \\
\hline
\end{tabular}

Grasses were harvested at Arlington and Marshfield using a rotary (lawn) mower with an attached bag to collect forage from a $1.5 \times 0.5 \mathrm{~m}$ area from the center of the plot. First plots were cut to an $8-\mathrm{cm}$ height and then to a $2.5-\mathrm{cm}$ stubble by adjusting mower-blade height, and the quality was calculated as a weighted average from both cutting heights. Two cutting heights were taken to measure the change in proportion of dry matter in each height over winter as discussed in Riesterer et al. (2000b). A composite of both cutting heights was used to estimated quality because it was assumed that animals would likely graze to $2.5 \mathrm{~cm}$ if forage was a challenge to find under snow. At Lancaster, 3 randomly selected $0.2 \mathrm{~m}^{2}$ subsamples per plot were clipped before grazing to a $2.5-\mathrm{cm}$ stubble.

All samples were dried in a $55^{\circ} \mathrm{C}$ forced-air oven for 1 week. Due to soil contamination in the samples from the low cutting heights and offseason harvest dates, all forage quality was reported on an organic matter (OM) basis. Dry samples were ground in a Wiley mill through a 2-mm screen. Ground samples were then scanned with a near infrared reflectance spectrophotometer (NIRSystem, Inc.1, Silver Spring, Md., model number 6500) to predict the following quality parameters: crude protein $(\mathrm{CP})$, neutral detergent and acid detergent fibers (NDF and ADF), in vitro organic matter digestibility (IVOMD), and OM. After all samples 
were scanned, the data was centered and then approximately $10 \%$ of the samples were selected for wet chemistry analysis. Equations were calibrated from existing pasture equations and modified with the wet chemistry results.

Wet chemistry performed on the selected samples followed the procedures outlined in the Forage Analysis Procedures of the National Forage Testing Association (Undersander et al. 1993). Acid detergent fiber was determined according to the Association of Official Analytical Chemists (AOAC 1990b), CP was determined using the macro copper catalyst Kjeldahl method (AOAC 1990c), and OM was determined by ashing samples in a muffle furnace for 8 hours at $550^{\circ} \mathrm{C}$ (AOAC 1990a). Neutral detergent fiber analysis followed Goering and Van Soest (1970) and Van Soest et al. (1991) methods modified by Mertens (1992). In vitro organic matter digestibility was determined according to the methods of Tilley and Terry (1963).

Metabolizable energy for maintenance requirements of ruminants was calculated from in vitro organic matter digestibility (IVOMD) in a series of equations. First, total digestible nutrients (TDN, \%OM) was assumed to be equal to IVOMD since ether extract is low in forages and ash has been removed (Van Soest 1994). Digestible energy (DE, Mcal kg ${ }^{-1} \mathrm{OM}$ ) was calculated using the equation from Swift (1957) as follows:

$$
\mathrm{DE}=\mathrm{TDN}(\%) * .04409
$$

Metabolizable energy (ME, Mcal kg-1 OM) was calculated with an equation from Moe and Tyrrell (1976):

$$
\mathrm{ME}=-0.45+1.01 \mathrm{DE}
$$

Increased maintenance energy requirements needed in environments below animal's lower critical temperature were calculated with the following equation (NRC 1981a):

$$
\mathrm{ME}^{*}=\mathrm{A}(\mathrm{LCT}-\mathrm{T}) / \mathrm{I}
$$

where,

$\mathrm{ME}^{*}=$ additional maintenance energy $\left(\right.$ Mcal day ${ }^{-1}$ )

$\mathrm{A}=$ body surface area $\left(\mathrm{m}^{2}\right)$, note: $(\mathrm{A}=.09 \mathrm{BW} 0.75, \mathrm{BW}=$ body weight in $\mathrm{kg}$ )

LCT $=$ lower critical temperature $\left({ }^{\circ} \mathrm{C}\right)$

$\mathrm{T}=$ ambient temperature $\left({ }^{\circ} \mathrm{C}\right)$

$\mathrm{I}=$ total insulation of animal $\left[{ }^{\circ} \mathrm{C}\left(\mathrm{Mcal} \mathrm{m}^{2}\right.\right.$ (ay) $\left.{ }^{-1}\right]$

The experimental design was a stripsplit-plot in complete blocks with 4 replicates (Gomez and Gomez 1984). The vertical factor was fertility treatments, the horizontal factor was harvest dates, and the sub-plot factor was grass species and cultivars. The experimental design was chosen for convenience and to place maximum precision on interactions involving harvest dates and fertility treatments (Milliken and Johnson 1998). The initial analysis of variance (ANOVA) used the model in Table 3 with the addition of years as a split-plot-in-time factor (Steel et al. 1996). Results from the initial ANOVA generally showed year by treatment interactions to be non-significant and few changes in ranking of treatments between years. Therefore, years were averaged and data were analyzed by the ANOVA model in Table 3. Occasional missing data values were estimated by SAS Proc GLM and inserted without adding degrees of freedom (SAS 1985, Steel et al. 1996). Lancaster data were analyzed separately from Arlington and Marshfield because of differences in defoliation methods. The location effect for Lancaster was excluded from the former model, and the year effect was included as a split-plot-in-time factor (Steel et al. 1996). All effects in both ANOVA models were assumed to be fixed, except for blocks. Comparison between means was made using Fisher's LSD at $\mathrm{P}<0.05$.

\section{Results}

\section{Crude Protein}

Crude protein (CP) levels of stockpiled forage, averaged over all factors, were surprisingly low in October at $115 \mathrm{~g} \mathrm{~kg}^{-1}$ (ranging from 88 to $142 \mathrm{~g} \mathrm{~kg}^{-1}$ across all sites) (Table 4). Previous research has shown that $\mathrm{CP}$ of stockpiled forage ranges from 70 to $220 \mathrm{~g} \mathrm{~kg}^{-1}$, averaging about 140 $\mathrm{g} \mathrm{kg}^{-1}$ (Bryan et al. 1970, Gardner and Hunt, 1955, Matches et al. 1973, Taylor and Templeton 1976, Wedin et al. 1966). In our study, $\mathrm{CP}$ concentration was based on the entire plant above a $2.5-\mathrm{cm}$ stubble, which likely increased the proportion of old, brown, and senesced leaf material and leaf sheaths vs. younger greener leaves above this height. Although complete harvest details were not always given in previous studies, we speculate that the combination of a lower cutting height and freezing temperatures in Wisconsin which may have accelerated cell leaching, both likely contributed to the lower CP levels in our study compared to other research.

The Marshfield site ranked the highest in $\mathrm{CP}$, followed by Lancaster, and then Arlington, averaging 120,110, and $95 \mathrm{~g}$ $\mathrm{kg}^{-1}$, respectively, across offseason har-
Table 3. Form of analysis of variance for standing forage dry matter at 2 locations.

\begin{tabular}{lrl}
\hline \hline & & \multicolumn{1}{c}{ F-test } \\
Source of variation & df & denomina- \\
tor & & \\
\hline Location (L) & 1 & - \\
Blocks/L & 6 & - \\
Harvest date (H) & 2 & Error(a) \\
L x H & 2 & Error(a) \\
Error(a) & 12 & Error(c) \\
Fertility treatments (F) & 3 & Error(b) \\
L x F & 3 & Error(b) \\
Error(b) & 18 & Error(c) \\
H x F & 6 & Error(c) \\
L x H x F & 6 & Error(c) \\
Error(c) & 36 & Error(d) \\
Species (S) & 6 & Error(d) \\
S x L & 6 & Error(d) \\
S x H & 12 & Error(d) \\
S x L x H & 12 & Error(d) \\
S x F & 18 & Error(d) \\
S x L x F & 18 & Error(d) \\
S x H x F & 36 & Error(d) \\
S x L x H x F & 36 & Error(d) \\
Error(d) & 432 & \\
\hline
\end{tabular}

vests (Table 4). Crude protein concentration of stockpiled forage did not change throughout the winter at Arlington, perhaps due to the initial low values (Table 4). Crude protein concentration declined at both Marshfield and Lancaster in late autumn by 16.3 and $17.1 \%$, respectively. Crude protein levels did not decline further beyond December at Lancaster while increases of $12.1 \%$ in late winter were measured at Marshfield.

October to December declines of CP concentration occurred in all species at both Marshfield and Lancaster but only in quackgrass and smooth bromegrass at Arlington (Table 4). Crude protein levels of tall fescue declined from $121 \mathrm{~g} \mathrm{~kg}^{-1}$ in October to $92 \mathrm{~g} \mathrm{~kg}^{-1}$ in November in Virginia (Brown et al., 1963). Losses in CP concentration from October to December were about $10 \%$ for tall fescue and both varieties of orchardgrass, and almost $20 \%$ for quackgrass and smooth bromegrass, averaged over all sites. Crude protein concentration of timothy and reed canarygrass also declined rapidly after October, the latter species in agreement with Bryan et al. (1970).

Crude protein estimates were higher for all species in March than December at Marshfield. Tall fescue, timothy and both orchardgrass varieties had CP-concentration increases up to $21.1 \%$ in late winter. An early study in Europe reported little or no decline in $\mathrm{CP}$ concentration of timothy and orchardgrass from October to January 
Table 4. Mean crude protein concentration of 7 stockpiled grasses on 3 offseason harvest dates at Arlington, Marshfield, and Lancaster, Wisc. Means are averaged across $4 \mathrm{~N}$ treatments, 2 years, and 4 replicates.

\begin{tabular}{|c|c|c|c|c|c|}
\hline \multirow[b]{2}{*}{ Location } & \multirow[b]{2}{*}{ Species } & \multicolumn{3}{|c|}{ Harvest date } & \multirow[b]{2}{*}{ Mean } \\
\hline & & October & December & March & \\
\hline & & & $--(\mathrm{g} \mathrm{kg}$ & $\cdots$ & $\cdots$ \\
\hline \multicolumn{6}{|l|}{ Arlington } \\
\hline & Orchardgrass, late & 99 & 94 & 98 & 97 \\
\hline & Orchgardgrass early & 97 & 95 & 99 & 97 \\
\hline & Quackgrass & 103 & 95 & 96 & 98 \\
\hline & Reed canarygrass & 95 & 93 & 87 & 92 \\
\hline & Smooth bromegrass & 104 & 96 & 101 & 100 \\
\hline & Tall fescue & 88 & 90 & 89 & 89 \\
\hline & Timothy & 96 & 93 & 99 & 96 \\
\hline & $\operatorname{LSD}(0.05)^{1}$ & 4 & 4 & 4 & 2 \\
\hline & Mean & 97 & 94 & 95 & \\
\hline \multirow[t]{9}{*}{ Marshfield } & Orchardgrass, late & 126 & 109 & 132 & 122 \\
\hline & Orchardgrass, early & 124 & 110 & 128 & 121 \\
\hline & Quackgrass & 137 & 115 & 125 & 126 \\
\hline & Reed canarygrass & 137 & 110 & 120 & 122 \\
\hline & Smooth bromegrass & 142 & 113 & 124 & 127 \\
\hline & Tall fescue & 116 & 97 & 113 & 108 \\
\hline & Timothy & 125 & 102 & 120 & 116 \\
\hline & $\operatorname{LSD}(0.05)^{1}$ & 4 & 4 & 4 & 2 \\
\hline & Mean & 129 & 108 & 123 & \\
\hline \multicolumn{6}{|l|}{ Lancaster } \\
\hline & Orchardgrass, late & 122 & 108 & 110 & 114 \\
\hline & Orchardgrass, early & 126 & 111 & 108 & 115 \\
\hline & Quackgrass & 137 & 103 & 110 & 116 \\
\hline & Reed canarygrass & 123 & 101 & 94 & 106 \\
\hline & Smooth bromegrass & 134 & 106 & 109 & 116 \\
\hline & Tall fescue & 106 & 95 & 98 & 100 \\
\hline & Timothy & 115 & 92 & 100 & 103 \\
\hline & $\operatorname{LSD}(0.05)^{1}$ & 6 & 6 & 6 & 4 \\
\hline & Mean & 123 & 102 & 104 & \\
\hline
\end{tabular}

LSD for harvest $\mathrm{x}$ location mean over species is 3 at Arlington \& Marshfield, and 5 at Lancaster.

(Hughes, 1954). High organic matter losses over winter as reported by Riesterer et al. (2000b) likely accounted for this increase, as CP did not increase per se.

Species generally ranked the same at all sites and at each harvest date. Smooth bromegrass and quackgrass ranked highest in $\mathrm{CP}$ concentration, followed by both varieties of orchardgrass. All species ranked higher than tall fescue and timothy. Similarly, reed canarygrass was higher in $\mathrm{CP}$ than tall fescue in Iowa (Bryan et al., 1970, Wedin et al., 1966), and orchardgrass ranked higher than timothy in Scotland (Corbett 1957).

The addition of $67 \mathrm{~kg} \mathrm{~N} \mathrm{ha}^{-1}$ on 1 August improved CP concentration by an average of $10.5 \%$ averaged over sites. However, the earlier-season $\mathrm{N}$ treatments [F168(2) and F168(3)] had no effect on $\mathrm{CP}$ content (data not shown). The influence on $\mathrm{N}$ on $\mathrm{CP}$ concentration was variable across sites, only notable in October at Arlington, while its effect at Lancaster and Marshfield was evident only during December and March. Dry soil conditions at Lancaster in addition to late-autumn leaf senescence at Marshfield may explain the 'deferred' response to $\mathrm{N}$.

Addition of $\mathrm{N}$ generally increased the $\mathrm{CP}$ concentration of most species at all sites (Table 5). There was no significant fertilizer by harvest date interaction. Smooth bromegrass and quackgrass ranked first or second under all $\mathrm{N}$ treatments and all sites, while timothy, reed canarygrass, and tall fescue ranked the lowest in $\mathrm{CP}$ concentration.

\section{Fiber}

Both neutral detergent fiber (NDF) and acid detergent fiber (ADF) of stockpiled forage increased by 10.8 to $15.6 \%$, respectively, over winter across sites (Tables 6 and 7) similar to previously reported results in Ohio (Penrose et al. 1994). The majority of the NDF increase over winter
$(7.8 \%)$ occurred from October to December while the majority of ADF increase $(11.3 \%)$ occurred after December.

Neutral detergent fiber and ADF increased from October to December in most species at each site (Tables 6 and 7). Reed canarygrass increased the most by about $12.0 \%$ from October to December, while all others increased from 5.3 to $7.6 \%$ during this time over all sites.

Species generally ranked the same in fiber across harvest dates at Arlington and Marshfield while there was some inconsistency at Lancaster (Tables 6 and 7). Timothy consistently ranked first or second with lowest NDF and ADF, with Lancaster as a major exception. Quackgrass and reed canarygrass usually ranked last with the highest NDF and ADF at all harvest dates across sites with the major exception of quackgrass at Lancaster.

Neutral detergent fiber and ADF response to added $\mathrm{N}$ was inconsistent across sites (Table 8). Similar to what Collins (1991) found with tall fescue in Kentucky, $\mathrm{N}$ application decreased NDF by $2.3 \%$ and ADF by $6.7 \%$ at Arlington. However, there was no significant change in either NDF or ADF at Lancaster or Marshfield. Generally, the spring-and-fallapplied $\mathrm{N}$ treatments [F168(2) and F168(3)] were not different than the fallonly $\mathrm{N}$ treatment [F67(1)], therefore, all 3 added- $\mathrm{N}$ treatments were averaged together in the fiber tables.

Neutral detergent fiber values of individual species were generally similar over all $\mathrm{N}$ treatments (Table 8). Small NDF decreases at Arlington of 2.7 to $3.8 \%$ for the late-maturing orchardgrass, quackgrass, timothy, and smooth bromegrass were due to added N. Less differences were found at Lancaster and Marshfield. There have been no other reports on NDF values of stockpiled forage besides tall fescue, and for this species, NDF was not affected by $\mathrm{N}$ fertilization (Collins 1991).

All species responded to $\mathrm{N}$ at Arlington with decreased ADF contents (Table 8). Decreases in ADF ranged from $4.7 \%$ for tall fescue up to $9.2 \%$ for the late-maturing orchardgrass. However, quackgrass was the only species at Marshfield to respond to added $\mathrm{N}$ with decreased ADF. No species responded to $\mathrm{N}$ at Lancaster. Species ranked similarly on all $\mathrm{N}$ treatments at Arlington and Marshfield. 
Table 5. Mean crude protein concentration of 7 stockpiled grasses on $4 \mathrm{~N}$ treatmentsat Arlington, Marshfield, and Lancaster, Wisc. Means are averaged over 3 offseason harvest dates, and 4 replicates.

\begin{tabular}{|c|c|c|c|c|c|}
\hline \multirow[b]{2}{*}{ Location } & \multirow[b]{2}{*}{ Species } & \multicolumn{3}{|c|}{$\mathrm{N}$ treatment ${ }^{\top}$} & \multirow[b]{2}{*}{ F168(3) } \\
\hline & & FO & F67(1) & $\mathrm{F} 168(2)$ & \\
\hline \multicolumn{6}{|c|}{ Arlington \& Marshfield } \\
\hline & Orchardgrass, late & 98 & 103 & 110 & 106 \\
\hline & Orchardgrass early & 96 & 105 & 109 & 106 \\
\hline & Quackgrass & 97 & 108 & 114 & 109 \\
\hline & Reed canarygrass & 97 & 99 & 103 & 105 \\
\hline & Smooth bromegrass & 101 & 108 & 111 & 112 \\
\hline & Tall fescue & 90 & 95 & 98 & 94 \\
\hline & Timothy & 94 & 104 & 104 & 102 \\
\hline & $\operatorname{LSD}(0.05)^{2}$ & 4 & 4 & 4 & 4 \\
\hline & Mean & 96 & 103 & 107 & 105 \\
\hline \multicolumn{6}{|l|}{ Lancaster } \\
\hline & Orchardgrass, late & 91 & 109 & 104 & 101 \\
\hline & Orchardgrass, early & 90 & 110 & 107 & 103 \\
\hline & Quackgrass & 93 & 99 & 102 & 100 \\
\hline & Reed canarygrass & 86 & 93 & 94 & 98 \\
\hline & Smooth bromegrass & 91 & 106 & 106 & 109 \\
\hline & Tall fescue & 87 & 93 & 91 & 92 \\
\hline & Timothy & 82 & 95 & 93 & 86 \\
\hline & $\operatorname{LSD}(0.05)^{2}$ & 7 & 7 & 7 & 7 \\
\hline & Mean & 89 & 101 & 99 & 98 \\
\hline
\end{tabular}

${ }^{1} \mathrm{~F} 0=$ no N; F67(1) $=67 \mathrm{~kg} \mathrm{n} \mathrm{ha}^{-1}$ was applied 1 Aug.; F168(2) = $101 \mathrm{~kg} \mathrm{n} \mathrm{ha}^{-1}$ was applied on $1 \mathrm{Jun}$. and $67 \mathrm{~kg} \mathrm{~N} \mathrm{ha}^{-1}$ was applied on 1 Aug.; F168(3) $=45 \mathrm{~kg} \mathrm{~N} \mathrm{ha}^{-1}$ was applied $10 \mathrm{Apr}$., $56 \mathrm{~kg} \mathrm{~N}^{-1}$ was applied on $1 \mathrm{Jun}$., and $67 \mathrm{~kg} \mathrm{~N}$ $\mathrm{ha}^{-1}$ was applied on 1 Aug.

${ }^{2}$ LSD for fertilitity means over species is 2 at Arlington and Marshfield and 3 at Lancaster.

Table 6. Mean neutral detergent fiber concentration of 7 stockpiled grasses on 3 offseason harvest dates at Arlington, Marshfield, and Lancaster, Wisc. Means are averaged over $4 \mathrm{~N}$ treatments, 2 years, and 4 replicates.

\begin{tabular}{|c|c|c|c|c|c|}
\hline \multirow[b]{2}{*}{ Location } & \multirow[b]{2}{*}{ Species } & \multicolumn{3}{|c|}{ Harvest date } & \multirow[b]{2}{*}{ Mean } \\
\hline & & October & December & March & \\
\hline & & $\ldots \ldots$ & $\overline{-(\mathrm{g} \mathrm{kg}}$ & $\ldots-\cdots$ & 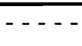 \\
\hline \multirow[t]{10}{*}{ Arlington } & & & & & \\
\hline & Orchardgrass, late & 612 & 670 & 703 & 661 \\
\hline & Orchardgrass early & 620 & 671 & 707 & 666 \\
\hline & Quackgrass & 665 & 702 & 725 & 698 \\
\hline & Reed canarygrass & 640 & 700 & 738 & 693 \\
\hline & Smooth bromegrass & 644 & 688 & 712 & 681 \\
\hline & Tall fescue & 619 & 679 & 713 & 670 \\
\hline & Timothy & 602 & 659 & 709 & 657 \\
\hline & $\operatorname{LSD}(0.05)^{1}$ & 10 & 10 & 10 & 6 \\
\hline & Mean & 629 & 681 & 715 & \\
\hline \multicolumn{6}{|l|}{ Marshfield } \\
\hline & Orchardgrass, late & 625 & 637 & 674 & 645 \\
\hline & Orchardgrass, early & 641 & 632 & 683 & 652 \\
\hline & Quackgrass & 625 & 659 & 681 & 655 \\
\hline & Reed canarygrass & 595 & 661 & 691 & 649 \\
\hline & Smooth bromegrass & 612 & 649 & 693 & 651 \\
\hline & Tall fescue & 645 & 635 & 701 & 660 \\
\hline & Timothy & 608 & 632 & 688 & 643 \\
\hline & $\operatorname{LSD}(0.05)^{1}$ & 10 & 10 & 10 & 6 \\
\hline & Mean & 621 & 645 & 689 & \\
\hline \multicolumn{6}{|l|}{ Lancaster } \\
\hline & Orchardgrass, late & 526 & 595 & 587 & 569 \\
\hline & Orchardgrass, early & 547 & 609 & 599 & 585 \\
\hline & Quackgrass & 540 & 582 & 568 & 563 \\
\hline & Reed canarygrass & 517 & 632 & 612 & 587 \\
\hline & Smooth bromegrass & 524 & 590 & 592 & 569 \\
\hline & Tall fescue & 523 & 613 & 623 & 586 \\
\hline & Timothy & 554 & 610 & 601 & 588 \\
\hline & $\operatorname{LSD}(0.05)^{2}$ & 13 & 13 & 13 & 8 \\
\hline & Mean & 533 & 605 & 597 & \\
\hline
\end{tabular}

LSD for comparing location-harvest means over species is 10 at Arlington and Marshfield and 14 at Lancaster.

\section{Digestibility}

Stockpiled forage remained highly digestible throughout the winter, with an average of $655 \mathrm{~g} \mathrm{~kg}^{-1}$ in March (Table 9). In vitro organic matter digestibility (IVOMD) declined from October to March by $10.8 \%$ across all sites, similar to declines noted in Missouri (Ocumpaugh and Matches 1977). The largest IVOMD losses occurred from December to March across all sites with the largest declines at Lancaster (7.8\%) and Marshfield (11.1\%). Increased ADF and NDF contents over winter in this study support this digestibility decline.

All species declined in IVOMD from October to December at Arlington and Lancaster, and all but tall fescue and both varieties of orchardgrass declined at Marshfield (Table 9). Quackgrass declined the least from October to December across sites with a $1.5 \%$ decrease in IVOMD while reed canarygrass declined the most with a $7.0 \%$ decrease. Continued growth and maturation of reed canarygrass stems in early autumn likely contributed to its quick decline in IVOMD.

In vitro organic matter digestibility of smooth bromegrass, reed canarygrass, and quackgrass did not decline beyond December at Arlington, but IVOMD for all other species-site combinations declined from December to March. In vitro organic matter digestibility of reed canarygrass declined the least from December to March $(5.2 \%)$ while early-maturing orchardgrass declined the most (8.4\%).

Species generally ranked the same in IVOMD at all 3 sites and harvest dates (Table 9). Timothy and late-maturing orchardgrass generally ranked the highest for all harvest dates at Arlington and Marshfield, followed by early-maturing orchardgrass. In contrast, at Berkshire, UK, IVOMD of stockpiled tall fescue was $3.0 \%$ higher than stockpiled orchardgrass (Baker et al., 1965). There were less obvious differences in IVOMD at Lancaster, with the exception that quackgrass and reed canarygrass generally ranked lowest in IVOMD. Both Bryan et al. (1970) and Wedin et al. (1966) found tall fescue to be more digestible than reed canarygrass, but there are no other reports on digestibility of stockpiled timothy, smooth bromegrass or quackgrass.

In vitro organic matter digestibility was not affected by $\mathrm{N}$ treatment (data not shown). Some researchers have reported small digestibility increases in stockpiled forage of 1 to $4 \%$ with the addition of 60 $\mathrm{kg} \mathrm{N} \mathrm{ha}{ }^{-1}$ (Archer and Decker 1977, 
Table 7. Mean acid detergent firber concentration of 7 stockpiled grasses on 3 offseason harvest dates at Arlington, Marshfield, and Lancaster, Wisc. Means are averaged over $4 \mathrm{~N}$ treatments, 2 years, and 4 replicates.

\begin{tabular}{|c|c|c|c|c|c|}
\hline \multirow[b]{2}{*}{ Location } & \multirow[b]{2}{*}{ Species } & \multicolumn{3}{|c|}{ Harvest date } & \multirow[b]{2}{*}{ Mean } \\
\hline & & October & December & March & \\
\hline \multicolumn{6}{|l|}{ Arlington } \\
\hline & Orchardgrass, late & 388 & 427 & 478 & 431 \\
\hline & Orchardgrass early & 400 & 416 & 474 & 430 \\
\hline & Quackgrass & 440 & 452 & 514 & 469 \\
\hline & Reed canarygrass & 408 & 434 & 502 & 448 \\
\hline & Smooth bromegrass & 431 & 447 & 497 & 459 \\
\hline & Tall fescue & 371 & 405 & 462 & 413 \\
\hline & Timothy & 374 & 409 & 480 & 421 \\
\hline & $\begin{array}{l}\text { LSD }(0.05)^{1} \\
\text { Mean }\end{array}$ & $\begin{array}{c}12 \\
402\end{array}$ & $\begin{array}{c}12 \\
427\end{array}$ & $\begin{array}{c}12 \\
487\end{array}$ & 7 \\
\hline \multicolumn{6}{|c|}{ Marshfield } \\
\hline & Orchardgrass, late & 385 & 377 & 431 & 398 \\
\hline & Orchardgrass, early & 389 & 371 & 425 & 395 \\
\hline & Quackgrass & 385 & 388 & 438 & 404 \\
\hline & Reed canarygrass & 371 & 388 & 434 & 398 \\
\hline & Smooth bromegrass & 384 & 391 & 448 & 407 \\
\hline & Tall fescue & 380 & 352 & 420 & 384 \\
\hline & Timothy & 366 & 368 & 434 & 390 \\
\hline & $\begin{array}{l}\operatorname{LSD}(0.05)^{1} \\
\text { Mean }\end{array}$ & $\begin{array}{c}12 \\
380\end{array}$ & $\begin{array}{c}12 \\
377\end{array}$ & $\begin{array}{c}12 \\
433\end{array}$ & 7 \\
\hline \multicolumn{6}{|l|}{ Lancaster } \\
\hline & Orchardgrass, late & 324 & 372 & 386 & 361 \\
\hline & Orchardgrass, early & 326 & 375 & 389 & 363 \\
\hline & Quackgrass & 328 & 366 & 377 & 357 \\
\hline & Reed canarygrass & 307 & 374 & 400 & 360 \\
\hline & Smooth bromegrass & 324 & 371 & 385 & 360 \\
\hline & Tall fescue & 298 & 345 & 377 & 340 \\
\hline & Timothy & 321 & 385 & 390 & 365 \\
\hline & $\begin{array}{l}\operatorname{LSD}(0.05)^{2} \\
\text { Mean }\end{array}$ & $\begin{array}{c}6 \\
318\end{array}$ & $\begin{array}{c}6 \\
370\end{array}$ & $\begin{array}{c}6 \\
386\end{array}$ & 4 \\
\hline
\end{tabular}

LSD for location-harvest mean is 14 for Arlington and Marshfield and 6 at Lancaster.

Balasko 1977), while some authors found no increase (Eck et al. 1981).

Generally, IVOMD of each species was not affected by $\mathrm{N}$ treatment with the exception that quackgrass and smooth bromegrass were 2.2 to $4.4 \%$ higher in IVOMD with the addition of $\mathrm{N}$, averaged across Arlington and Marshfield (Table 10). In West Virginia, responses of tall fescue to added $\mathrm{N}$ were over $3.0 \%$ (Balasko 1977, Kroth et al. 1977) but smaller increases of $1.0 \%$ were noted in Maryland (Archer and Decker 1977).

\section{Discussion}

\section{Quality Changes}

Forage yields were highest at Marshfield and lowest at Lancaster, as previously reported (Riesterer et al. 2000b). Different environments can affect quality components. Soil-water limitations at Lancaster may have decreased the
Cellular differences among grasses can influence quality. The early decline in IVOMD of reed canarygrass may have resulted from a higher degree of leaching of cell solubles upon freezing unlike orchardgrass which has an increased tolerance to freezing conditions (Premachandra et al. 1993). In Iowa, soluble carbohydrate percentage was maintained in tall fescue over the fall sampling period but was substantially reduced in reed canarygrass during this time (Wedin et al. 1966). In Kentucky, soluble carbohydrates in tall fescue increased from October to December (Dougherty 1981, Taylor and Templeton 1976). Furthermore, green fractions of tall fescue exhibited a high, but slowly declining, sugar content beyond December while brown fractions were consistently low in sugar (Taylor and Templeton 1976).

Due to early decline in quality, earlyautumn grazing of quackgrass, smooth bromegrass, reed canarygrass, and timothy is suggested to obtain maximum quality intake. Stockpiled orchardgrass and tall fescue are suitable for grazing any time. It would be beneficial for producers to seed some pasture into orchardgrass or tall fescue which can be grazed later in winter when other pasture species have poor nutritional value. An alternative to reseeding pasture is to reserve stockpiled reed canarygrass, smooth bromegrass or quackgrass for low maintenance livestock.

\section{Stockpiled Forage Quality vs. Animal Requirements}

Feed requirements of livestock depend on maintenance needs and production levels of the animals. Nutrient content of the forage must match the energy, fiber and protein requirements of the animal. Several classes of livestock can obtain at least some, if not all, of their nutrient requirements from stockpiled forage under most winter conditions, assuming adequate stocking rate is maintained. Additionally, animals should have good body condition before outwintering. Stocking rates can be calculated from yields of stockpiled forage (Riesterer et al. 2000b).

Crude protein levels of stockpiled forage in our study averaged $108 \mathrm{~g} \mathrm{~kg}^{-1}$ over the entire winter. In October, stockpiled forage with CP levels of $116 \mathrm{~g} \mathrm{~kg}^{-1}$ is marginally low to meet the requirements of dairy heifers larger than $250 \mathrm{~kg}$ and gaining up to $0.8 \mathrm{~kg} \mathrm{day}^{-1}$, as well as latelactation dairy cows and dry dairy cows, all of which require levels of $\mathrm{CP}$ at $120 \mathrm{~g}$ 
Table 8. Mean neutral detergent firber (NDF) and acid detergent (ADF) fiber concentration of 7 stockpiled grasses on $2 \mathrm{~N}$ treatments at Arlington, Marshfield, and Lancaster, Wisc. Means are averaged over 3 offseason harvest dates, 2 years, and 4 replicates.

\begin{tabular}{|c|c|c|c|c|c|}
\hline \multirow[b]{2}{*}{ Location } & \multirow[b]{2}{*}{ Species } & \multicolumn{2}{|c|}{$\frac{\mathrm{NDF}}{\mathrm{N}}$} & \multicolumn{2}{|c|}{ ADF } \\
\hline & & No $\mathrm{N}$ & $\mathrm{N}$ & No N & $\mathrm{N}$ \\
\hline & & $\cdots$ & $-\ldots$ & $\ldots \ldots$ & $\ldots$ \\
\hline Arlington & Orchardgrass, late & 676 & 656 & 465 & $42 ?$ \\
\hline & Orchardgrass early & $\begin{array}{l}6 / 0 \\
673\end{array}$ & $\begin{array}{l}050 \\
664\end{array}$ & $\begin{array}{l}403 \\
453\end{array}$ & $\begin{array}{l}422 \\
425\end{array}$ \\
\hline & Quackgrass & $\begin{array}{l}6 / 3 \\
715\end{array}$ & 693 & $\begin{array}{l}453 \\
500\end{array}$ & 425 \\
\hline & Reed canarygrass & 700 & 691 & $\begin{array}{l}500 \\
473\end{array}$ & 463 \\
\hline & Smooth bromegrass & 702 & $\begin{array}{l}091 \\
675\end{array}$ & $\begin{array}{l}473 \\
491\end{array}$ & 443 \\
\hline & Tall fescue & 674 & $\begin{array}{l}013 \\
669\end{array}$ & $\begin{array}{l}491 \\
429\end{array}$ & 452 \\
\hline & Timothy & 670 & $\begin{array}{l}069 \\
652\end{array}$ & 429 & 409 \\
\hline & Timothy & $6 / 0$ & 652 & 439 & 417 \\
\hline & $\operatorname{LSD}(0.05)^{2}$ & 11 & 11 & 13 & 13 \\
\hline & Mean & 687 & 671 & 464 & 433 \\
\hline \multicolumn{6}{|c|}{ Marshfield } \\
\hline & Orchardgrass, late & 633 & 647 & 385 & 387 \\
\hline & Orchardgrass, early & 634 & 646 & 385 & 381 \\
\hline & Quackgrass & 673 & 658 & 413 & 391 \\
\hline & Reed canarygrass & 658 & 664 & 400 & 392 \\
\hline & Smooth bromegrass & 661 & 661 & 412 & 401 \\
\hline & Tall fescue & 636 & 652 & 367 & 368 \\
\hline & Timothy & 638 & 644 & 379 & 377 \\
\hline & $\operatorname{LSD}(0.05)^{2}$ & 11 & 11 & 13 & 13 \\
\hline & Mean & 647 & 653 & 392 & 385 \\
\hline \multicolumn{6}{|l|}{ Lancaster } \\
\hline & Orchardgrass, late & 567 & 563 & 365 & 356 \\
\hline & Orchardgrass, early & 571 & 587 & 364 & 364 \\
\hline & Quackgrass & 543 & 563 & 355 & 357 \\
\hline & Reed canarygrass & 566 & 588 & 359 & 361 \\
\hline & Smooth bromegrass & 552 & 567 & 362 & 358 \\
\hline & Tall fescue & 581 & 584 & 340 & 341 \\
\hline & Timothy & 573 & 589 & 360 & 367 \\
\hline & $\operatorname{LSD}(0.05)^{2}$ & 15 & 15 & 7 & 7 \\
\hline & Mean & 565 & 577 & 358 & 358 \\
\hline
\end{tabular}

The 3 added- $\mathrm{N}$ treatments were not different and have been averaged.

${ }^{2}$ LSD for comparing NDF and ADF location-fertility means over species is 6 and 8 at Arlington and Marshfield respectively, and 7 and 3 at Lancaster respectively.

$\mathrm{kg}^{-1}$ (NRC 1989). Dairy heifers younger than six months of age would not receive their required $160 \mathrm{~g} \mathrm{~kg}^{-1} \mathrm{CP}$ from stockpiled forage (NRC, 1989). However, throughout winter, CP levels of stockpiled forage will generally satisfy the requirements of dry beef cows, gestating beef heifers, lactating beef cows (producing less than $14 \mathrm{~kg}$ milk day ${ }^{-1}$ ), and ewes, all of which require 60 to $120 \mathrm{~g} \mathrm{~kg}^{-1}$ crude protein depending on stage of gestation and lactation (NRC 1984, NRC 1985). Crude proteins levels remained above $90 \mathrm{~g}$ $\mathrm{kg}^{-1}$ throughout winter, the critical dietary level to satisfy microbial $\mathrm{N}$ requirement (Waghorn and Barry 1987).

Stockpiled forage from this study would have provided sufficient energy for several classes of cattle. Energy content of our stockpiled forage averaged $2.82 \mathrm{Mcal} \mathrm{ME}$ $\mathrm{kg}^{-1} \mathrm{OM}$ in October, $2.69 \mathrm{Mcal} \mathrm{ME} \mathrm{kg}{ }^{-1}$ $\mathrm{OM}$ in December, and $2.47 \mathrm{Mcal} \mathrm{ME} \mathrm{kg}{ }^{-1}$
$\mathrm{OM}$ in March. Energy remains available for growing beef cattle at weight gains up to $0.9 \mathrm{~kg} \mathrm{day}^{-1}$ as well as pregnant and nursing beef cows in most winter conditions (NRC 1984). In a study in Ohio, pregnant beef cows grazing a mixture of stockpiled tall fescue, orchardgrass, Kentucky bluegrass (Poa pratensis) and white clover (Trifolium repens) through December gained of $0.8 \mathrm{~kg}$ head $^{-1}$ day $^{-1}$ and gained from 0.3 to 0.9 points in body condition (Turner et al. 1998). Beef cattle gained from 0.4 to $1.3 \mathrm{~kg}$ head ${ }^{-1}$ day $^{-1}$ while grazing tall fescue and -0.1 to $1.0 \mathrm{~kg}$ head $^{-1}$ day $^{-1}$ while grazing orchardgrass (Baker et al. 1965).

Energy in stockpiled forage of the current study would have met the maintenance energy requirement of grazing adult sheep weighing up to $70 \mathrm{~kg}$. Stockpiled forage would also have supplied adequate energy to growing lambs of $30 \mathrm{~kg}$ gaining
$0.05 \mathrm{~kg}$ body weight day ${ }^{-1}$. Lambs grazing timothy pasture from December through mid-March showed no animal weight change over winter and the animals overwintered in healthy and thrifty condition (Griffith and Hutton 1936). However, ewes in late gestation would require energy supplementation as it is common for ewes to give birth to 2 or 3 lambs. Ewes pastured over winter on stockpiled tall fescue pasture in Ohio scored slightly below average in milking ability and gained 4.1 $\mathrm{kg}$ head $^{-1}$, only one-third the weight gained by silage-fed ewes (Parker and Van Keuren, 1967). Lambs born to winter-pastured ewes were strong at birth and comparable in birth weight and 30-day weight to the conventionally fed group.

Additional energy will be needed when animals are subjected to extreme winter conditions but levels of energy will vary according to class of livestock and environmental conditions (Table 11). As ambient temperatures fall below the lower critical temperature (LCT) of the animal, insulative and behavioral responses are inadequate to maintain core body temperature. Below the LCT, animals must increase metabolic heat production to maintain homeothermy which increases energy requirement of the animal. Increased intake of $30 \%$ can be expected as temperatures approach $-15^{\circ} \mathrm{C}$, assuming conditions are dry, but intake depression of 5 to $30 \%$ can accompany temperatures below $-25^{\circ} \mathrm{C}$ with extensive precipitation and muddy conditions (NRC 1981b). In climates with rainy, wet winters, and extremely severe winter conditions, animals should have access to a covered shelter and a wind break since intake will not meet additional energy requirements.

Fiber levels of stockpiled forage in October were typical of grasses in the growing season (367 $\mathrm{g} \mathrm{kg}^{-1} \mathrm{ADF}$ and 594 $\mathrm{g} \mathrm{kg}^{-1} \mathrm{NDF}$ ) but levels increased to 392 and $667 \mathrm{~g} \mathrm{~kg}^{-1} \mathrm{ADF}$ and NDF, respectively, by March. Animals at maintenance generally can obtain adequate energy from grass diets in most winter conditions without NDF restricting intake. Additionally, animals at maintenance have slower passage rates allowing digesta to be more completely fermented by ruminal microbes. The maximum NDF concentration of the diet that will not restrict intake for mature beef cows ranges from 750 to $850 \mathrm{~g} \mathrm{~kg}^{-1}$ DM (Mertens 1985). Extra energy in the form of grain should be fed to animals on stockpiled pasture when temperatures fall below $-25^{\circ} \mathrm{C}$. In severe weather, it is likely that the high NDF val- 
Table 9. Mean in vitro organic matter digestibility of 7 stockpiled grasses on 3 offseason harvest dates at Arlington, Marshfield, and Lancaster, Wisc. Means are averaged over $4 \mathrm{~N}$ rates, 2 years, and 4 replicates.

\begin{tabular}{|c|c|c|c|c|c|}
\hline \multirow[b]{2}{*}{ Location } & \multirow[b]{2}{*}{ Species } & \multicolumn{3}{|c|}{ Harvest date } & \multirow[b]{2}{*}{ Mean } \\
\hline & & October & December & March & \\
\hline \multicolumn{6}{|l|}{ Arlington } \\
\hline & Orchardgrass, late & 759 & 725 & 698 & 727 \\
\hline & Orchardgrass early & 745 & 717 & 686 & 716 \\
\hline & Quackgrass & 697 & 674 & 678 & 683 \\
\hline & Reed canarygrass & 696 & 643 & 651 & 6633 \\
\hline & Smooth bromegrass & 744 & 712 & 705 & 720 \\
\hline & Tall fescue & 744 & 701 & 677 & 707 \\
\hline & Timothy & 780 & 741 & 710 & 744 \\
\hline & $\operatorname{LSD}(0.05)^{1}$ & 12 & 12 & 12 & 7 \\
\hline & Mean & 738 & 702 & 686 & \\
\hline \multicolumn{6}{|c|}{ Marshfield } \\
\hline & Orchardgrass, late & 743 & 736 & 641 & 707 \\
\hline & Orchardgrass, early & 736 & 733 & 637 & 702 \\
\hline & Quackgrass & 701 & 673 & 617 & 664 \\
\hline & Reed canarygrass & 710 & 657 & 608 & 658 \\
\hline & Smooth bromegrass & 738 & 711 & 643 & 698 \\
\hline & Tall fescue & 736 & 739 & 643 & 706 \\
\hline & Timothy & 757 & 738 & 648 & 715 \\
\hline & $\operatorname{LSD}(0.05)^{1}$ & 12 & 12 & 12 & 7 \\
\hline & Mean & 732 & 713 & 634 & \\
\hline \multicolumn{6}{|l|}{ Lancaster } \\
\hline & Orchardgrass, late & 764 & 712 & 664 & 713 \\
\hline & Orchardgrass, early & 742 & 707 & 652 & 700 \\
\hline & Quackgrass & 674 & 692 & 627 & 664 \\
\hline & Reed canarygrass & 709 & 667 & 621 & 666 \\
\hline & Smooth bromegrass & 749 & 728 & 657 & 711 \\
\hline & Tall fescue & 751 & 692 & 647 & 697 \\
\hline & Timothy & 739 & 713 & 656 & 702 \\
\hline & $\operatorname{LSD}(0.05)^{2}$ & 13 & 13 & 13 & 7 \\
\hline & Mean & 733 & 701 & 646 & \\
\hline
\end{tabular}

LSD for location-harvest mean over species is 10 at Arlington and Marshfield and 9 at Lancaster.

ues of stockpiled forage will restrict intake before adequate energy is obtained, similar to the effect of high levels of NDF on intake of high producing dairy cows (Van Soest 1994).

High producing dairy cows require intake levels up to $25 \mathrm{~kg} \mathrm{DM}_{\text {day }}{ }^{-1}$ to meet their energy demand for milk production (NRC, 1989). These animals cannot obtain this level of intake on stockpiled forage due to physical constraints of the rumen from high NDF. Furthermore, the high passage rate of digesta reduces the amount of microbial cell wall digestion and potential energy is lost to the animal. Therefore stockpiled forage should not be fed to high producing dairy cows as the main source of forage.

\section{Conclusions}

Stockpiling forage in late summer until the end of the growing season is an effective way to extend grazing while providing adequate-quality forage for many classes of livestock. Maintaining animal body condition is dependent on energy and protein content of the forage assuming intake is not limited.

Quality of stockpiled forage in Wisconsin decreased over winter but remained at adequate levels for several classes of livestock such as beef cows, dry dairy cows and sheep. In vitro organic matter digestibility remained high over winter at levels near $700 \mathrm{~g} \mathrm{~kg}^{-1}$. Quality of reed canarygrass decreases rapidly in late autumn with more accelerated increases in fiber and higher losses in IVOMD than any other species. Therefore, reed canarygrass should be utilized early if maximum quality is the goal. Otherwise, reed canarygrass should be allocated to the lowest maintenance group. Both orchardgrass varieties are excellent choices for stockpiling due to a relatively high $\mathrm{CP}$ and IVDOM throughout winter. Tall fescue and timothy would require the most protein supplementation, both maintaining the lowest level of $\mathrm{CP}$ while smooth bromegrass and quackgrass continued to be highest in $\mathrm{CP}$. Addition of $\mathrm{N}$ generally improved CP concentration but did not affect digestibility or fiber levels.

Any of the 7 stockpiled grasses have adequate quality for animal classes with low nutrient requirements such as dry beef cows and sheep. However, animals with higher nutrient requirements will require protein and energy supplementation beyond December. Stockpiled forage should not be fed to lactating dairy cows as the sole source of forage as the fiber

Table 10. Mean in vitro organic matter digestibility of 7 stockpiled grasses on $2 \mathrm{~N}$ treatments at Arlington, Marshfield, and Lancaster, Wisc. Means are averaged over 3 offseason harvest dates, 2 years and 4 replicates

\begin{tabular}{|c|c|c|c|}
\hline \multirow{2}{*}{ Location } & \multirow[b]{2}{*}{ Species } & \multicolumn{2}{|c|}{$\underline{\mathrm{N} \text { treatment }}{ }^{1}$} \\
\hline & & No $\mathrm{N}$ & $\mathrm{N}$ \\
\hline & & \multicolumn{2}{|c|}{$--\left(\mathrm{g} \mathrm{kg}^{-1}\right)--$} \\
\hline \multirow{10}{*}{ Arlington } & & & \\
\hline & Orchardgrass, late & 729 & 727 \\
\hline & Orchardgrass early & 719 & 714 \\
\hline & Quackgrass & 683 & 684 \\
\hline & Reed canarygrass & 670 & 662 \\
\hline & Smooth bromegrass & 693 & 729 \\
\hline & Tall fescue & 706 & 708 \\
\hline & Timothy & 740 & 744 \\
\hline & $\operatorname{LSD}(0.05)^{2}$ & 14 & 14 \\
\hline & Mean & 706 & 710 \\
\hline \multicolumn{4}{|c|}{ Marshfield } \\
\hline & Orchardgrass, late & 712 & 724 \\
\hline & Orchardgrass, early & 726 & 711 \\
\hline & Quackgrass & 645 & 675 \\
\hline & Reed canarygrass & 647 & 657 \\
\hline & Smooth bromegrass & 680 & 707 \\
\hline & Tall fescue & 720 & 726 \\
\hline & Timothy & 717 & 723 \\
\hline & $\operatorname{LSD}(0.05)^{2}$ & 14 & 14 \\
\hline & Mean & 693 & 703 \\
\hline \multicolumn{4}{|c|}{ Lancaster } \\
\hline & Orchardgrass, late & 716 & 712 \\
\hline & Orchardgrass, early & 705 & 695 \\
\hline & Quackgrass & 670 & 662 \\
\hline & Reed canarygrass & 663 & 665 \\
\hline & Smooth bromegrass & 702 & 710 \\
\hline & Tall fescue & 693 & 697 \\
\hline & Timothy & 714 & 695 \\
\hline & $\operatorname{LSD}(0.05)^{2}$ & 15 & 15 \\
\hline & Mean & 695 & 691 \\
\hline
\end{tabular}

The 3-added-N treatments were not different and have peen averaged.

LSD for location-fertility mean over species is 6 at all sites. 
Table 11. Estimates of additional energy requirements for different classes of cattle in environments below their lower critical temperatures. ${ }^{1}$

\begin{tabular}{|c|c|c|c|c|c|c|}
\hline \multirow[b]{3}{*}{ Class of livestock } & \multicolumn{6}{|c|}{ Additional energy required } \\
\hline & \multicolumn{3}{|c|}{${ }^{\circ} \mathrm{C}$} & \multicolumn{3}{|c|}{${ }^{\circ} \mathrm{C}$} \\
\hline & -10 & -20 & -30 & -10 & -20 & -30 \\
\hline & \multicolumn{3}{|c|}{ - - (Mcal ME day $\left.{ }^{-1}\right)$ - - } & \multicolumn{3}{|c|}{ - - (kg grain day $\left.{ }^{-12}\right)--$} \\
\hline \multicolumn{7}{|l|}{ Beef } \\
\hline \multicolumn{7}{|l|}{ Adult, lactating (500) kg) } \\
\hline dry, low wind & 0 & 0 & 2.97 & 0 & 0 & 0.9 \\
\hline no shelter, $10 \mathrm{mph}$ wind & 0 & 0 & 5.70 & 0 & 0 & 1.7 \\
\hline \multicolumn{7}{|l|}{ Adult, Dry $(500 \mathrm{~kg})$} \\
\hline dry, low wind & 0 & 0 & 5.34 & 0 & 0 & 1.6 \\
\hline no shelter & 1.07 & 7.08 & 12.69 & 0.3 & 2.1 & 3.7 \\
\hline \multicolumn{7}{|l|}{ 6-month old steer or heifer $(100 \mathrm{~kg})$} \\
\hline dry, low wind & 0 & 0.42 & 1.82 & 0 & 0.1 & 0.5 \\
\hline no shelter, $10 \mathrm{mph}$ wind & 5.57 & 8.37 & 11.17 & 1.6 & 2.4 & 3.2 \\
\hline \multicolumn{7}{|l|}{ Yearling steer or heifer $(300 \mathrm{~kg})$} \\
\hline dry, low wind & 0 & 0 & 0 & 0 & 0 & 0 \\
\hline no shelter, $10 \mathrm{mph}$ wind & 0.25 & 5.25 & 10.25 & 0.1 & 1.5 & 3.0 \\
\hline \multicolumn{7}{|l|}{ Newborn $(40 \mathrm{~kg})$} \\
\hline dry, low wind & 3.30 & 5.17 & 7.04 & - & - & - \\
\hline \multicolumn{7}{|l|}{ Dairy } \\
\hline \multicolumn{7}{|l|}{ Dry $(650 \mathrm{~kg})$} \\
\hline dry, low wind & 0 & 3.48 & 9.28 & 0. & 1.0 & 2.7 \\
\hline no shelter, $10 \mathrm{mph}$ wind & 9.86 & 18.15 & 26.43 & 2.9 & 5.3 & 7.7 \\
\hline \multicolumn{7}{|l|}{ Yearling steer or heifer $(250 \mathrm{~kg})$} \\
\hline dry, low wind & 1.32 & 5.70 & 10.08 & 0.3 & 1.7 & 2.9 \\
\hline no shelter, $10 \mathrm{mph}$ wind & 7.98 & 13.68 & 19.38 & 2.3 & 4.0 & 5.6 \\
\hline
\end{tabular}

${ }^{1}$ Adapted from NRC 1981. Lower critical temperature of the animal is at which point basal heat production is not enough to maintain homeothermy.

${ }^{2}$ Grain refers to cracked corn with $3.44 \mathrm{Mcal} \mathrm{ME} \mathrm{kg}^{-1} \mathrm{DM}$.

concentration will limit intake and therefore energy.

\section{Literature Cited}

Archer K.A. and A.M. Decker. 1977. Autumn-accumulated tall fescue and orchardgrass. I. Growth and quality as influenced by nitrogen and soil temperature. Agron. J. 9:601-605.

Association of Official Analytical Chemists. 1990a. Ash of Animal Feed. (942.05). Official Methods of Analysis, $15^{\text {th }}$ Edition.

Association of Official Analytical Chemists. 1990b. Fiber (Acid Detergent) and Lignin in Animal Feed. (973.18). Official Methods of Analysis Fiber, $15^{\text {th }}$ Ed.

Association of Official Analytical Chemists. 1990c. Protein (Crude) Determination in Animal Feed: Copper Catalyst Kjeldahl Method. (984.13). Official Methods of Analysis, $15^{\text {th }} \mathrm{Ed}$.

Baker, H.K., J.R.A. Chard, and W.E. Hughes. 1965. A comparison of cocksfoot and tall fescue-dominant swards for out-ofseason production. J. British Grassl. Soc. 20:84-90.

Balasko, J.A. 1977. Effects of N, P, and K fertilization on yield and quality of tall fescue forage in winter. Agron. J. 69:425-428.

Brown, R.H., R.E. Blaser, and J.P. Fontenot. 1963. Digestibility of fall grown Kentucky 31 fescue. Agron. J. 55:321-324.
Bryan, W.B., W.F. Wedin, and R.L. Vetter. 1970. Evaluation of reed canarygrass and tall fescue as spring-summer and fall-saved pasture. Agron. J. 62:75-80.

Casler, M.D. and W.H. Goodwin. 1998. Agronomic performance of quackgrass and hybrid wheatgrass populations. Crop Sci. 38:1369-1377.

Collins, M. 1991. Nitrogen effects on yield and forage quality of perennial ryegrass and tall fescue. Agron. J. 83:588-595.

Corbett, J.L. 1957. Studies on the extension of the grazing season. I. The evaluation of selected strains of some grass species for winter grazing. J. British Grassl. Soc. 12:81-96.

Decker, A.M. 1988. Maximizing the grazing season. p. 31-42. In: J.B. Cropper (ed.), Pasture in the Northeast Region of the United States. Workshop Proc. 26-28 Apr. 1988. Northeast Regional Agr. Eng. Ser., West Springfield, Mass.

Dougherty, C.T. 1981. Stockpiling of coolseason grasses in autumn, p. 590-592. In J.A. Smith and V.W. Hays (eds.) Proc. XIV Int. Grassl. Congr., Lexington, Ky. 15-24 June 1981. Westview Press, Boulder, Colo.

Eck, H.V., T. Martinez, and G.C. Wilson. 1981. Tall fescue Festuca arundinacea and smooth bromegrass Bromus inermis. I. Nitrogen and water requirements. Agron. J. 73:446-452.

Gardner, A.L. and I.V. Hunt. 1955. Winter utilization of cocksfoot. J. British Grassl. Soc. 10:306-316.
Goering, H.K. and P.J. Van Soest. 1970. Forage fiber analysis (apparatus, reagents, procedures, and some applications). USDA ARS. Handb. number 379:20--28.

Gomez, K.A. and A.A. Gomez. 1984. Statistical procedures for agricultural research. $2^{\text {nd }}$ ed. John Wiley \& Sons, NY.

Griffith, M. and P.M.G Hutton. 1936. The wintering of sheep on temporary grassesContinued. Welsh J. Agr. 12:126-130.

Hughes, G. Pearson. 1954. The production and utilization of winter grass. J. Agr. Sci. 45:179--201.

Kroth E., R. Mattas, L. Meinke, and A. Matches. 1977. Maximizing production potential of tall fescue. Agron. J. 69:319-322.

Matches, A.G., J.B. Travis, and F.A. Martz. 1973. Yield and quality of tall fescue stockpiled for winter grazing. p. 54-57. In: Research in Agronomy 1973. Univ. of Missouri-Columbia. Misc. Pub. 73-75.

Mertens, D.R. 1985. Factors influencing feed intake in lactation dairy cows: from theory to application using neutral detergent fiber, $\mathrm{p}$. 1-18. In: Proc. Georgia Nutr. Conf. for the Feed Industry. University of Georgia, Athens, Ga.

Mertens, D.R. 1992. Critical conditions in determining detergent fiber, p. C1-C8 In: D.J. Undersander, D.R. Mertens, and N. Thiex (eds), Proc. National Forage Testing Assoc. Forage Analysis Workshop. Denver, Colo. 
Milliken, G.A. and D.E. Johnson. 1998. Analysis of Messy Data. Vol 1: Designed Experiments. Chapman and Hall, New York, N.Y.

Moe, P.W. and A.F. Tyrrell. 1976. Estimating metabolizable and net energy of feeds, p. 232-236. In: P.V. Fonnesbeck et al. (eds), Proc. First Int. Symposium on Feed Composition, Animal Nutrient Requirements, and Computerization of Diets. 11-16 July 1976. Utah State University, Logan, Ut.

National Research Council. 1981a. Nutritional Energetics of Domestic Animals and Glossary of Energy Terms. Nat. Acad. of Sci., Washington, D.C.

National Research Council. 1981b. Effects of Environment on Nutrient Requirements of Domestic Animals. National Academy of Sciences, Washington, D.C.

National Research Council. 1984. Nutritional Requirements of Beef Cattle. Nat. Acad. of Sci., Washington, D.C., Washington, D.C.

National Research Council. 1985. Nutritional Requirements of Sheep. Nat. Acad. of Sci., Washington, D.C.

National Research Council. 1989. Nutritional Requirements of Dairy Cattle. Nat. Acad. of Sci., Washington, D.C.

Ocumpaugh, W.R., and A.G. Matches. 1977. Autumn-winter yield and quality of tall fescue. Agron. J. 69:639--643.

Parker, C.F. and R.W. Van Keuren. 1967. Winter pasture for sheep. Ohio Report on Research and Develop. 49:69-70.

Penrose C.D., H.M. Bartholomew, and R.M. Sulc. 1994. Stockpiling tall fescue for winter grazing. Ohio State Univ.. Agron. Factsheet 023.
Premachandra, G.S., H. Saneoka, K. Fujita, and S. Ogata. 1993. Seasonal changes in leaf water relations and cell membrane stability in orchardgrass (Dactylis glomerata). J. Agr. Sci. (Cambridge). 121:169-175.

Riesterer, J.L., M.D. Casler, D.J. Undersander, and D.K. Combs. 2000a. Seasonal yield distribution of cool-season grasses following winter defoliation. Agron. J. 92:974-980.

Riesterer, J.L., D.J. Undersander, M.D. Casler, and D.K. Combs. 2000b. Forage yield of stockpiled perennial grasses in the upper-Midwest USA. Agron. J. 92:740-747.

SAS Institute, Inc. 1985. SAS user's guide: Statistics, $5^{\text {th }}$ ed. SAS Inst., Inc., Cary, N.C.

Schulte, E.E., J.B. Peters, and P.H. Hodgson. 1987. Wisconsin procedures for soil testing, plant analysis, and feed and forage analysis. Soil and Plant Analysis Lab, University of Wisconsin-Extension, Madison, Wisc.

Steele R.G.D., J.H Torrie, and D.A. Dickey. 1996. Principles and Procedures of Statistics. $3^{\text {rd }}$ Edition. McGraw-Hill Book Co. New York. N.Y.

Swift, R.W. 1957. The caloric value of TDN. J. Anim. Sci. 16:753-756.

Taylor, T.H. and W.C. Templeton, Jr. 1976. Stockpiling Kentucky bluegrass and tall fescue forage for winter pasturage. Agron. J. 68:235--239.

Tilley, J.M. and R.A. Terry. 1963. A twostage technique for the digestion of forage crops. J. British Grassl. Soc. 18:104-111.

Turner, T., J. Fisher, E.M. Vollborn, and G. Balthaser. 1998. Beef cow weight change during the fall extended grazing season, utilizing stockpile forages in Southern Ohio, p.
80-82. In: M. Phillips (ed) American Forage and Grassland Council Proc. Indianapolis, Ind. 8-10 Mar. 1998. Amer. Forage and Grassl. Council, Georgetown, Tex.

Undersander, D.J., D.R. Mertens, N. Thiex. 1993. Forage Analyses Procedures. National Forage Testing Association, Omaha, Nebr. 68137.

Van Keuren, R.W. 1970. All-season grazing for beef cows. Ohio Agriculture Research and Development Center Research Summary. 43:1-6.

Van Soest, P J. 1994. Nutritional ecology of the rumir ant. 2nd Ed. Comstock Publishing Associates, Ithaca, N.Y.

Van S jest, P.J., J.B. Robertson, and B.A. L - wis. 1991. Methods for dietary fiber, neucral detergent fiber and non-starch polysaccharides in relation to animal nutrition. J. Dairy Sci. 74:3583-3597.

Waghorn, G.C. and T.N. Barry. 1987. Pasture as a nutrient source. p. 21-37. In: A.M. Nicol (ed) Livestock feeding on pasture. Occasional Publication No. 10. New Zealand Society of Animal Production. Private Bag, Hamilton, New Zealand.

Wedin, W.F., I.T. Carlson, and R.L. Vetter. 1966. Studies on nutritive value of fall-saved forage using rumen fermentation and chemical analysis, p. 424-428. In: A.G.G. Hill, V.U. Mustonen, S. Pulli and M. Latvala (eds.) Proc.X Int. Grassland Congr., Helsinki, Finland. 7-16 July 1966. Valtioneuvoston Kirjapaino, Helsinki, Finland. 